\title{
Proses Komunikasi Pemasaran dalam Penyelenggaraan Event Online (Studi Kasus pada PT. MarkPlus Indonesia)
}

\author{
Abigail Jessica ${ }^{1}$, Riris Loisa ${ }^{2 *}$ \\ ${ }^{1}$ Fakultas Ilmu Komunikasi, Universitas Tarumanagara, Jakarta \\ Email: abigailjessica2@gmail.com \\ ${ }^{2}$ Fakultas Ilmu Komunikasi, Universitas Tarumanagara, Jakarta* \\ Email: ririsl@fikom.untar.ac.id
}

Masuk tanggal : 15-12-2021, revisi tanggal :06-01-2022, diterima untuk diterbitkan tanggal : 16-01-2022

\begin{abstract}
The development of times is increasingly modern and tends to lead to increasingly advanced conditions and make the growth of digital era very rapid in supporting every community activity. PT. MarkPlus Indonesia is a company engaged in consulting, marketing research, education, and media and thecommunity. Markeeter's Mice is a division at PT. Markplus who works on an event that has run various events both at home and abroad. Innovation needs to be done to improve company marketing activities to become more effective. This study aims to determine the process of marketing communication in the implementation of online events conducted at PT. MarkPlus Indonesia. The theoretical basis of this research is marketing communication and the concept of MICE, New Media, events, and online events. This study uses a qualitative approach. Data was collected through interviews, observation, and documentation. Researchers used coding analysis techniques in processing research data. The results in this study found that marketing communication applied by PT. MarkPlus Indonesia in marketing is in the form of Above the Line which means that through advertising in print media and online media and Below the line which means through sponsorship and direct marketing. Implementation of online events conducted by PT. MarkPlus Indonesia begins with the preparation stage, implementation and reporting phase which includes the evaluation stage.
\end{abstract}

Keywords: marketing communications, online events, PT. MarkPlus Indonesia

\begin{abstract}
Abstrak
Perkembangan zaman yang semakin modern dan cenderung mengarah kepada keadaan yang semakinmaju dan membuat pertumbuhan era digital sangat pesat dalam menjamin setiap kegiatan masyarakat. PT. MarkPlus Indonesia merupakan perusahaan yang bergerak pada bidang riset pemasaran, konsultasi, pendidikan, dan media ataupun komunitas. Markeeter's MICE merupakan divisi pada PT. MarkPlus yang mengerjakan suatu event yang sudah menjalankan berbagai macam event baik di dalam maupun di luar negeri. Inovasi perlu dilakukan untuk meningkatkan kegiatan pemasaran perusahaan agar menjadi lebih efektif. Penelitian memiliki tujuan untuk mengetahui proses komunikasi pemasaran dalam penyelenggaraan event online yang dilakukan pada PT. MarkPlus Indonesia. Landasan teori penelitian ini adalah komunikasi pemasaran serta konsep MICE, New Media, event dan event online. Penelitian ini menggunakan pendekatan kualitatif. Pengumpulan data dilakukan melalui wawancara, observasi dan dokumentasi. Peneliti menggunakan teknik analisis coding dalam pengolahan data penelitian. Hasil dalam penelitian ini menemukan bahwa komunikasi Pemasaran yang diterapkan PT. MarkPlus Indonesia dalam melakukan pemasaran yakni berupa above the line yang berarti bahwa melalui iklan di media cetak dan media online serta below the line yang berarti melalui sponsorship dan direct marketing. Penyelenggaraan event online yang dilakukan oleh PT. MarkPlus Indonesia diawali dengantahap persiapan,
\end{abstract}


pelaksanaan dan tahap pelaporan yang termasuk tahap evaluasi.

Kata Kunci: acara daring, komunikasi pemasaran, PT. MarkPlus Indonesia

\section{Pendahuluan}

Kondisi pandemi Covid-19 saat ini membuat setiap perusahaan kembali menyusun strategi yang lebih tepat agar dapat beradaptasi. Salah satu strategi yang tepat yakni event, Noor menjelaskan bahwa event adalah suatu kegiatan yang dilaksanakan sebagai bentuk memperingati suatu hal yang terbulang penting bagi suatu individu selaku konsumen pada waktu yang tertenu serta melibatkan lingkungan pada masyarakat (Rahma, 2017). Secara luasnya, event dapat didefinisikan sebagai kegiatan yang diselenggarakan oleh suatu organisasi dalam waktu tertentu untuk mendatangkan masyarakat selaku konsumen pada suatu lokasi agar dapat mendapatkan informasi serta pengalaman yang penting dan tujuan lain sesuai dengan harapan perusahaan. Kegiatan acara atau event merupakan strategi suatuperusahaan untuk memenuhi kebutuhan konsumen yang berupa informasi maupun hiburan serta menjadi peluang besar dalam kegiatan pemasaran. Perkembangan teknologi yang semakin maju menjadi inovasi bagi suatu perusahaan untuk mengembangkan strategi pemasaran yang lebih efektif untuk meningkatkan brand awareness dan brand image perusahaan. Namun, kondisi pandemi Covid-19 saat ini membuat setiap perusahaan kembali menyusun strategi yang lebih tepat agar dapat beradaptasi. Salah satu strategi yang tepat yakni Event, menurut Noor, event merupakan kegiatan yang diselenggarakan untuk memperingati hal-hal penting bagi manusia selaku konsumen baik secara individu atau kelompok pada waktu tertentu dan melibatkan lingkungan masyarakat. (Rahma, 2017)

Zoom merupakan salah satu platform online yang paling banyak digunakan untuk melakukan interaksi sosial selama pandemi Covid-19. Pelaku event biasanya menggunakan platform Zoom untuk menjalankan event online. Aplikasi Zoom terdapat pilihan meeting dan webinar, kebanyakan para pelaku event menggunakan webinar sebagai jenis event online mereka. Webinar atau Web-based Seminar adalah salah satu teknologi dimana pengguna dapat mengadakan seminar, talkshow, diskusi, dan acara lainnya (Verma, 2010).

Perubahaan yang dihadapi oleh pelaku event tersebut melahirkan konsep baru dalam pemasaran atau marketing. Pemasaran merupakan suatu tahapan atau proses dalam merencanakan dan melaksanakan konsepsi, penetapan biaya dan harga, distribusi, ide, distribusi, barang maupun jasa agar dapat menciptakan nilai tukar yang kredibel dan membuat individu ataupun organisasi dapat merasa terpuaskan. (Kotler \& Keller, 2009).

PT MarkPlus Indonesia adalah salah satu perusahaan yang bergerak dalam bidang konsultan, riset pemasaran, pendidikan, media, dan komunitas. Didirikan pada tahun 1990 oleh Hermawan Kartajaya, MarkPlus berkembang menjadi perusahaan konsultan pemasaran premier di Asia Tenggara setelah konsisten dalam bidangnya serta sebagai penasihat strategi pemasaran bisnis yang kompeten. Dalam perusahaan ini, divisi yang mengerjakan suatu event terletak pada divisi Markeeter's MICE (Meeting, Incentive, Convention, and Exhibition) merupakan strategi event yang digunakan. Marketeer's sudah menjalankan berbagai macam event baik di dalam maupun di luar negeri sejak perusahaan ini didirikan tepatnya 31 tahun yang lalu. Namunsemenjak pandemi Covid-19 perusahaan ini harus mengikuti anjuran pemerintah untuk menerapkan sistem kerja Work From Home (WFH) sehingga 
Abigail Jessica, Riris Loisa: Proses Komunikasi Pemasaran dalam Penyelenggaraan Event Online (Studi Kasus pada PT. MarkPlus Indonesia)

kegiatan event yang biasanya dilakukan secara langsung atau offline harus diubah menjadi event berbasis online.

PT MarkPlus melakukan perubahan dan inovasi terhadap strategi perusahaannya untuk mengikuti kondisi sekarang ini. Inovasi dilakukan untuk meningkatkan kegiatan pemasaran perusahaan agar menjadi lebih efektif. Salah satu perubahan yang diterapkan yakni merubah kegiatan event yang awalnya bersifat offline menjadi event online.

Media sosial Instagram menjadi platform penting sebagai sarana memasarkan dan mempromosikan kegiatan event online yang diselenggarakan oleh PT MarkPlus. PT MarkPlus mengorganisasikan akun Instagram @ markplusinc yang memiliki 9.228 pengikut (followers). Banyaknya pengguna media sosial Instagram, menjadi peluang besar bagi PT MarkPlus dalam mempromosikan setiap kegiatan atau event serta masyarakat selaku konsumen dapat dengan mudah mencari atau mengakses informasiinformasi berkaitan dengan event online yang diselenggarakan oleh PT MarkPlus.

Berkaitan dengan uraian latar belakang di atas, peneliti ingin mengetahui bagaimana strategi komunikasi pemasaran yang dilakukan oleh PT MarkPlus dalam upaya menyelenggarakan event online bagi masyarakat. Penelitian ini bertujuan untuk mengetahui proses komunikasi pemasaran dalam penyelenggaraan event online.

Dalam proses pemasaran, komunikasi merupakan hal yang sangat penting terutama bagi pebisnis menjadi faktor penting dalam keberhasilan sebuah usaha. Pada proses komunikasi pemasaran proses menyampaikan umpan berupa pesan yang bersifat perusasif dalam memberikan penawaran suatu produk barang maupun jasa (Fitriah, 2018). Pemasaran sendiri adalah berbagai jenis kegiatan yang mana suatu perusahaan atau organisasi lain melakukan kegiatan jual beli terhadap nilai pertukaran terkait produk, ide maupun jasa antara perusahaan dengan konsumen (Firmansyah, 2019). Kotler \&Keller mengungkapkan bahwa komunikasi pemasaran sendiri adalah suatu sarana yang mana perusahaan berusaha untuk memberikan informasi, mengajak atau merayu, mengingatkan pelanggan terkait dengan produk maupun jasa yang diperjualkan. Terdapat beberapa tujuan dari komunikasi pemasaran yang meliputi:

- Komunikasi informatif, untuk menyebarluaskan informasi

- Komunikasi persuasif, mempengaruhi keputusan pembelian pada konsumen.

- Komunikasi mengingatkan kembali, membuat konsumen ingat untuk bertransaksi kembali.

Salah satu strategi pemasaran yang digunakan oleh event yaitu MICE. Menurut Kesrul, MICE diartikan sebagai suatu kegiatan kepariwisataan yang aktivitasnya merupakan perpaduan antara leisure danbusiness, biasanya melibatkan sekelompok orang secara bersama-sama (Desthiani \& Suwandi, 2019).

Seiring dengan perkembangan teknologi dan sosial budaya, perkembangan internet tidak dapat terlepas dari munculnya media baru atau New Media. Media baru adalah suatu istilah untuk mencakup perkembangan teknologi komunikasi massa digital dimana seseorang dapat melakukan interaksi di dunia maya menggunakan internet tanpa harus bertatap muka secara langsung. Media baru atau new media menurut Terry Flew dalam Michael Hartono dan Rizky Fauzi adalah media yang mencakup digitalisasi, konvergensi, interaktivitas, dan pengembangan jaringan terhadap pembuatan dan penyampaian suatu pesan (Hartono, 2019) Media digital saat ini sedang mengalami perkembangan teknologi menurut Alexandra Georgakopoulou dan Tereza Spilioti, mencakup media sosial (seperti Twitter, Facebook, Instagram, Pinterest, dan sebagainya), smartphones dengan kemampuan akses internet, online games, DVD, serta online streaming untuk video dan musik (Georgakopoulou \& 
Spilioti, 2016).

Event terbilang sebagai media komunikasi sebagai upaya untuk memberikan informasi dari suatu merek, organisasi maupun perusahaan yang dilakukan dengan cara berkomunikasi secara langsung pada konsumen ataupun publik internal perusahaan. Sumardy dan Yoris Sebastian mengatakan bahwa pengamat pemasaran dan event berperan besar dalam kegiatan komunikasi pemasaran (ITALIANI, 2013).

Event adalah cara yang dilakukan oleh suatu perusahaan agar dapat mengharmonisasikan hubungan emosional antara perusahaan dengan para konsumen. Tom Duncan mengatakan bahwa "event marketing is a promotional occasion designed to attract and involve a brand's target audience." Pelaksanaan event harud berdampak serta dapat menciptakan kesan yang dalam bagi para individu yang hadir dalam acara tersebut (Duncan, 2005). Event juga diterapkan sebagai marketing tools untukmeningkatkan awareness dan daya tarik yang lebih besar atau instan terhadap sebuah organisasi atau komunitas. Menurut Finney dan Sneat (2014), terdapat beberapa dimensi pada event marketing yang meliputi:

- Enterprise. Pada dimensi ini menjelaskan bahwa suatu perusahaan menciptakan sebuah inovasi acara yang bertujuan untuk menarik konsumen agar dapat mengetahui serta dapat merasakan suatu acara yang kreatif dan inovatif.

- Entertainment. Pada dimensi ini menjelaskan bahwa dalam pemasaran event harus dapat bermanfaat bagi konsumen baik dengan alasan untuk menghibur ataupun kebutuhan.

- Excitement. Pada dimensi ini menjelaskan bagaimana khalayak konsumen dapat merasakan kepuasan, kesenangan serta kebahagian yang tercipta dari adanya acara yang diselenggarakan (Limandono, 2018).

Manajemen Acara (event management) adalah suatu aktivitas kegiatan yang bersifatprofessional yang mengumpulkan dan mempertemukan orang-orang dengan minat yang sama dan tujuan tertentu. Manajemen Acara (event management) dapat digunakan untuk strategic marketing dan komunikasi oleh perusahaan dari berbagai ukuran. Perusahaan dapat mengambil manfaat dari promosi event sebagai cara untuk berkomunikasi dengan pelanggan saat ini yang cukup potensial. Misalnya, acara berfokus pada promosi sebuah produk dan dapat melakukan promosi melalui press conferences, promotional events atau product launches. Acara online (event online) adalah kegiatan yang diselenggarakan oleh suatu instansi untuk memperingati halhal penting dengan menggunakan bantuan suatu perangkat yang bernama internet dan media baru yang berbentuk media online. Menurut Goldblatt (2014), pada era kemajuan digital saat ini, berbagai kegiatan dapat dilakukan dengan memanfaatkan media digital seperti Zoom, Skype, Instagram dan lain sebagainya.

\section{Metode Penelitian}

Penelitian ini menggunakan metode pendekatan penelitian kualitatif, karena latar belakang serta rumusan permasalahan dalam penelitian ini berkaitan dengan proses komunikasi pemasaran yang bergantung pada pengamatan. Metode penelitian yang penulis gunakan yaitu studi kasus, yang dimana untuk mendeskripsikan hasil penelitian dan berusaha untuk mendapatkan gambaran mengenaikeadaaan secara menyeluruh. Studi kasus dapat diartikan sebagai strategi penelitian untuk menyelidiki suatu hal secara cermat dengan mengumpulkan informasi lengkap menggunakan produsedur pengumpulan data (Creswell, 2014). Dalam studi kasus, 
peneliti mengumpulkan datamengenai subjek dari keadaan masa sebelum, sekarang, dan lingkungan sekitarnya (Broto, 2016). Dengan menggunakan metode wawancara mendalam yang akan dijelaskan lebih lanjut nantinya, peneliti ingin menggali lebih dalam terkait proses komunikasi pemasaran PT. MarkPlus Indonesia dalam penyelenggaraan event online.

Subyek penelitian dideskripsikan sebagai informan yang memiliki arti sebagai individu yang dimanfaatkan sebagai penerimaan informasi mengenai situasi dan kondisi tempat penelitian (Sumiati, 2015). Dalam penelitian ini, subyek penelitiannya adalah PT. MarkPlus Indonesia. Dalam penelitian ini, obyek penelitiannya adalah event online yang diselenggarakan karena sebagai penggunaan strategi komunikasi pemasaran.

Penelitian ini menggunakan metode pengumpulan data dengan wawancara, observasi, dan dokumentasi. Dalam penelitian ini, peneliti mewawancarai empat informan untuk memperoleh data yang diperlukan. Penulis melakukan pengamatan secara langsung terhadap proses kegiatan event online di PT. MarkPlus Indonesia. Penulis mengumpulkan dokumentasi berupa foto kegiatan event online di PT. MarkPlus Indonesia. Pada penelitian ini, peneliti menganalisis data dengan menggunakan teknik coding terbuka atau pengkodean terbuka (open coding) dimana peneliti menganalisis kembali dan membandingkan hasil yang ditemukan berdasarkan dari wawancara, observasi maupun dokumentasi dalam penelitian ini. Untuk memastikan kebenaran data yang didapat dalam penelitian ini, peneliti menggunakan teknik triangulasi sumber data.

\section{Hasil Temuan dan Diskusi}

\section{Komunikasi Pemasaran yang Dilakukan di PT. MarkPlus}

PT MarkPlus menggunakan komunikasi pemasaran yang berupa komunikasi above the line dan below the line. Berdasarkan hasil wawancara dengan key informan pertama dan key informan kedua mengungkapkan bahwa komunikasi yang dilakukan MarkPlus berupa komunikasi above the line (melalui iklan di media cetak dan media online) dan below the line (melalui sponsorship dan direct marketing).

Dari hasil observasi peneliti, dapat ditemukan bahwa salah satu komunikasi pemasaran yang dilakukan oleh PT MarkPlus adalah komunikasi below the line (melalui sponsorship dan direct marketing). Dalam hal ini, PT MarkPlus memanfaatkan media sosial seperti Instagram sebagai salah satu media komunikasi pemasaran yang diterapkan.

\section{Proses Perencanaan Event yang Dilakukan oleh PT. MarkPlus}

Berdasarkan hasil wawancara dengan key informan kedua dan key informan ketigamengatakan bahwa proses perencanaan event yang dilakukan PT MarkPlus Indonesia dari awal sampai akhir yaitu menentukan ide, brainstorming creative concept, presentasi konsep, perencanaan gambar produksi, pembuatan $\mathrm{RAB}$ / anggaran biaya, menyusun rundown acara (quecard, mc script, dan seebagainya), proses approval client, proses finansial, proses produksi, proses loading di venue acara, rehearsal/ runthrough susunan acara, berdoa bersama, show time, proses unloading dan client meeting (evaluasi). Selain itu, peneliti juga mewawancarai key informan pertama terkait proses perencanaan event yang dilakukan PT MarkPlus Indonesia, ia mengatakan bahwa diawali dengan dealing dengan klien dan langsung direncanakan konsepnya, tanggal, lokasi, dan beberapa hal pendukung lainnya sampai dengan hari 
pelaksanaan hingga pelaporan mengenai event tersebut.

\section{Tahap Penyelenggaraan Event Online}

Berdasarkan hasil wawancaran dengan key informan pertama selaku Head of Production and Creative Marketeers MICE PTMarkPlus mengatakan bahwa tahaptahap tersebut berawal dari tahap persiapan, lalu dilanjutkan dengan tahap pelaksanaan, setelah tahap sebelumnya barulah memasuki tahap pelaporan kegiatan serta tahap evaluasi. Selain itu, peneliti juga mewawancarai Rachman selaku Senior Marketeers Community Activator PT MarkPlus mengatakan bahwa:

"Tahap pertama, membuat konsep setelah itu membuat anggaran biaya. Jika disetujui oleh client, kita melakukan brainstorming. Setelah itu, kami membuatkan media promosi, komunikasi channelnya. Pada akhirnya, kami menjalankan event tersebut. Setelah selesai menjalankan event, kami mengadakan reporting dan evaluasi terhadap event tersebut." -Rachman Julistia

\section{Manajemen Acara (Event Management) PT. MarkPlus}

Manajemen Acara (event management) merupakan suatu kegiatan bersifat professional yang mempersatukan individu-individu dengan keinginan serta kebutuhan yang sama dan tujuan tertentu. Menurut Bladen, Kennell dan Abson (2012), manajemen acara (event management) adalah suatu kegiatan organisasi maupun perusahaan serta membutuhkan koordinasi agar dapat memenuhi tujuan dari dilaksanakannya event tersebut.

Berdasarkan hasil wawancara dengan key informan pertama selaku Head of Production and Creative Marketeers MICE ia menjelaskan bahwa pada tahap perencanaan, awalnya melakukan kesepakatan dengan klien, dan langsung merencanakan konsepnya, tanggalnya, lokasinya, dan beberapa hal pendukung lain. Ia juga menambahkan bahwa tahapan dalam menyelenggarakan event online adalah dimulai dari tahap persiapan, tahap pelaksanaan, dan tahap pelaporan kegiatan yang didalamnya termasuk evaluasi.

Berkaitan dengan event management atau manajemen acara, berdasarkan hasil wawancara dengan key informan kedua selaku Senior Marketeers Community Activator PT MarkPlus Indonesia mengungkapkan bahwa dalam proses event management ini prosesnya berawal dengan mencari ide atau konsep terlebih dahulu. Namun, PT MarkPlus sendiri selalu memberikan paling tidak tiga (3) ide dan dari ideide tersebut dapat menentukan budget yang dibutuhkan. Ide yang pertama, konsep terbaik dengan harga terbaik. Ide kedua, konsep standard dengan harga standard (menengah). Ide ketiga, konsep biasa saja dengan harga murah. Setelah itu, PT MarkPlus Indonesia mempresentasikan ketiga ide tersebut kepada klien untuk menjelaskan setiap kelebihan kekurangan yang ada disetiap ide tersebut. Setelah klien menentukan pilihannya, PT MarkPlus melakukan brainstorming mengenai konsep dan teknis. Kemudian mereka menjelaskan kembali lebih detailnya tentang konsep dan teknis yang sudah kami buat kepada klien. Lalu, jika klien sudah menyetujuinya maka budget dapat diperoleh sesuai dengan apa yang sudah disepakati.

\section{Media Digital atau Online yang Digunakan oleh PT. MarkPlus}

Acara online (event online) adalah kegiatan yang diselenggarakan oleh suatu instansi untuk memperingati hal-hal penting dengan menggunakan bantuan suatu 
perangkat yang bernama internet dan media baru yang berbentuk media online. Menurut Goldblatt (2014), pada era kemajuan digital saat ini, berbagai kegiatan dapat dilakukan dengan memanfaatkan media digital seperti Zoom, Skype, Instagram dan lain sebagainya.

Berdasarkan hasil wawancara dengan key informan ahli (keempat) berkaitan dengan media digital (online) yang efektif digunakan pada saat ini sebagai media pemasaran, ia mengatakan bahwa media yang digunakan untuk pemasaran perusahaan itu tergantung dari target atau segmentasi pasar suatu perusahaan. Setelah mengetahui siapa target atau segementasi pasar, maka suatu perusahaan dapat mengidentifikasi media digital (online) yang efektif digunakan untuk pemasaran perusahaan.

\section{Hambatan-Hambatan dalam Proses Komunikasi Pemasaran PT. MarkPlus}

Hambatan komunikasi merupakan salah satu masalah yang kurang diperhatikan oleh kebanyakan orang, kelompok, maupun organisasi. Menurut Orbe dan Bruess dalam (Arifin et al., 2020), terdapat beberapa jenis hambatan, yaitu hambatan fisik yang berupa noise, jarak, psikologis yang berupa hambatan mental berkaitan dengan kesadaran, sosiologis, antropologis yang berupa perbedaan budaya, fisiologis yang mencakup setiap aspek fisik yang mengganggu proses komunikasi dan hambatan semantik yang berupa kata-kata sehingga dapat mengganggu perhatian komunikator dan komunikan terhadap pesan.

Berdasarkan hasil wawancara dengan key informan ahli yakni Anto selaku ahli komunikasi pemasaran politik menjelaskan bahwa hambatan-hambatan yang dialami perusahaan pada saat ini adalah pandemi Covid-19 karena ada banyak perusahaan yang belum siap untuk berubah menuju ke arah yang lebih modern dan memanfaatkan media digital. Namun, ada juga perusahaan yang sudah mempersiapkannya. Selain itu hambatan yang terjadi adalah paradigm pemasaran ke arah digital membutuhkan upaya yang lebih besar. Adanya hambatan pada daya beli masyarakat juga menjadi salah satu faktor hambatan pemasaran karena saat ini pun daya beli masyarakat masih terbilang rendah karena beberapa faktor yakni menurunnya perekonomian masyarakat sehingga pada saat ini tingkat persaingan sangat tinggi antar perusahaan.

Selain itu, terkait dengan hambatan dalam penyelenggaraan event, key informan pertama mengatakan bahwa dalam sepengetahuannya, hambatan dalam penyelenggaraan event yang paling sering terjadi adalah menyamakan persepsi antara klien dengan penyelenggara, dan bagaimana pihak PT MarkPlus Indonesia bisa mengkompilasi apa yang menjadi kebutuhan klien dengan budget yang tersedia dan terbatas. Berbeda dengan apa yang disampaikan oleh key informan pertama dan kedua, hasil wawancara dengan key informan ketiga mengatakan bahwa yang menjadi hambatan dalam penyelenggaraan event adalah peralatan (tools) dan manpower.

\section{Simpulan}

Komunikasi Pemasaran yang diterapkan PT MarkPlus Indonesia dalam melakukan pemasaran yakni berupa above the line yang berarti bahwa melalui iklan di media cetak dan media online serta below the line yang berarti melalui sponsorship dan direct marketing. Konsumen yang menjadi target pasar dari PT MarkPlus Indonesia adalah para orang-orang professional di bidang pemasaran. Selain itu, dengan melakukan komunikasi pemasaran yang tepat, PT MarkPlus Indonesia memiliki tujuan untuk meningkatkan kesadaran terhadap brand atau event yang diselenggarakan. PT MarkPlus Indonesia memanfaatkan media digital atau online 
yakni Instagram, TikTok, Youtube, Zoom Meeting dan Whatsapp sebagai media komunikasi pemasaran dan media pelaksaan event online.

Penyelenggaraan event online yang dilakukan oleh PT. MarkPlus Indonesia diawali dengan tahap persiapan, pelaksanaan dan tahap pelaporan yang termasuk tahap evaluasi. Dalam proses penyelenggaraan event online, PT MarkPlus melakukan tahap-tahapan yang berbeda dengan perusahaan lain yakni meliputi dengan menentukan ide, brainstorming creative concept, presentasi konsep, perencanaan gambar produksi, pembuatan RAB/ anggaran biaya, menyusun rundown acara (quecard, mc script, dan seebagainya), proses approval client, proses finansial, proses produksi, proses loading di venue acara, rehearsal/ runthrough susunan acara, berdoa bersama, show time, proses unloading dan client meeting (evaluasi).

Hambatan yang dihadapi PT MarkPlus Indonesia dalam menyelenggarakan event online terletak pada bidang offline seperti media cetak yang digunakan karena pada saat ini para marketer sudah banyak yang menggunakan media online dibandingkan media cetak serta juga banyak yang tidak menggunakan atau membaca majalah yang bersifat fisik. Selain itu, hambatan lain juga ditemukan pada peserta event online yang terkadang tidak memahami apa yang disampaikan (miskomunikasi) dalam event online yang diadakan oleh PT MarkPlus Indonesia serta adanya hambatan dalam penyelenggaraan event online lain yakni dari peralatan (tools) dan man power.

\section{Ucapan Terima Kasih}

Peneliti ingin mengucapkan terima kasih kepada Fakultas Ilmu Komunikasi Universitas Tarumanagara, narasumber, serta semua pihak yang turut membantu peneliti sehingga penelitian ini dapat diselesaikan.

\section{Daftar Pustaka}

Arifin, n. A., djamereng, a., \& ... (2020). Strategi Komunikasi Pemasaran Event Organizer Pt. Tiga Production Dalam Mendapatkan Kepercayaan Pelanggan. Jurnal Kajian Dakwah, 614-630. http://journal.uinalauddin.ac.id/index.php/washiyah/article/view/16230

Creswell, J. W. (2014). Research Design: Qualitative, Quantitative, and Mixed MethodsApproaches. 4th ed. Thousand Oaks, California: SAGE Publications.

Desthiani, U., \& Suwandi. (2019). Mice (Meeting, Incentive, Convention, Exhibition) (Issue 1). http://eprints.unpam.ac.id/8589/1/SKR0192_MICE.pdf

Duncan, T. (2005). Principles of Advertising and IMC. Boston: McGraw-Hill/Irwin.

Fitriah. (2018). Komunikasi Pemasaran Melalui Desain Visual. Yogyakarta: Grup Penerbitan CV Budi Utama.

Firmansyah. (2019). Komunikasi pemasaran. Pasuruan: CV. Penerbit Qiara Media.

Georgakopoulou, A., \& Spilioti, T. (2016). The Routledge Handbook of Language and Digital Communication. London, New York: Routledge.

Hartono, R. F. (2019). Hubungan antara Kampanye dengan ikap Remaja Sekolah Tinggi Ilmu Komunikasi Inter Studi. The concept that used of this. 1(1), 34-47.

Italiani, F. A. (2013). Bisma jurnal bisnis dan manajemen. Jurnal Bisnis Dan Manajemen Volume 6 No. 1 Agustus, 13(1), 43-51.

Kotler, P., \& Keller, K. L. (2009). Manajemen Pemasaran, Jilid. 1, Ed. 13. Jakarta: 
Abigail Jessica, Riris Loisa: Proses Komunikasi Pemasaran dalam Penyelenggaraan Event Online (Studi Kasus pada PT. MarkPlus Indonesia)

\section{Erlangga.}

Limandono, J. A. D. D. (2018). Pengaruh Content Marketing Dan Event Marketing Terhadap Customer Engagement Dengan Sosial Media Marketing Sebagai Variabel Moderasi Di Pakuwon City. Jurnal Strategi Pemasaran, 5(1), 11.

Mania, S. (2008). Observasi Sebagai Alat Evaluasi Dalam Dunia Pendidikan Dan Pengajaran. Lentera Pendidikan: Jurnal Ilmu Tarbiyah Dan Keguruan, 11(2), 220-233.https://doi.org/10.24252/lp.2008v11n2a7

Martin Lister, J. D. (2008). New Media: A Critical Introduction 2nd Edition. New Y ork:Routledge.

McQuail, D. (2011). Teori Komunikasi Massa. Jakarta: Salemba Humanika. 